\title{
The Boundaries of Article III: Delegation of Final Decisionmaking Authority to Magistrates
}

In the last decade Congress has steadily expanded the adjudicatory role of magistrates in federal district courts. When the office was created in $1968,{ }^{1}$ magistrates were limited to hearing nondispositive motions and conducting pre-trial conferences and hearings; ${ }^{2}$ final decisionmaking authority in all cases was reserved for the federal judge. In 1976, Congress allowed magistrates to undertake without the parties' consent "such additional duties as are not inconsistent with the Constitution and laws of the United States."3 Under this elastic provision, some magistrates exercised the authority to render final decisions when the parties consented. ${ }^{4}$ With the passage of the Federal Magistrate Act of 1979,5 Congress expressly granted magistrates the power, upon designation by the district court and consent of the parties, to conduct "any or all proceedings in a jury or nonjury civil matter" as well as criminal misdemeanor trials. ${ }^{6}$ Their judgments need not be reviewed before

1 Congress established the office of United States magistrate in the Federal Magistrates Act of 1968, Pub. L. No. 90-578, 82 Stat. 1107 (codified as amended at 18 U.S.C. $\S \S 3401-$ 3402 ; 28 U.S.C. $\$ \$ 631-639$ (1982)).

${ }^{2}$ Under the 1968 Act, a judge may designate a magistrate to preside over certain pretrial hearings, 28 U.S.C. $\$ 636(\mathrm{~b})(1)(\mathrm{A})$ (1982), to conduct evidentiary hearings and submit recommendations for disposition, $i d$. $\$ 636(\mathrm{~b})(1)(\mathrm{B})$, and to serve as a special master, $i d$. $\S 636(\mathrm{~b})(2)$.

${ }^{3}$ Pub. L. No. 94-577, 90 Stat. 2729, 2729 (codified as amended at 28 U.S.C. § 636(b)(3) (1982)). The 1976 amendments allowed the magistrate to be assigned pretrial matters, to hear nondispositive motions, and to serve as a special master. See id. These amendments were partly a response to the Supreme Court's decision in Wingo v. Wedding, 418 U.S. 461 (1974), which interpreted the statute to bar a magistrate from rendering decisions on habeas corpus petitions.

1 Courts adopted different local rules about consensual reference to magistrates. See, e.g., Behnami v. Golden Bear Family Restaurant, No. 78 C 1156, slip op. (N.D. Ill. Sept. 9, 1980) (discussing standards for judicial review of magistrate trial where local rules do not specifically provide for magistrate trial); Oliver v. Allison, 488 F. Supp. 885, 886 (D.D.C. 1980) (noting an experimental local rule allowing magistrates to conduct civil trials); McCabe, The Federal Magistrate Act of 1979, 16 HARv. J. on LEGIs. 343, 359-61 (1979) (observing that in 1978 "magistrates in over half of the district courts conducted 540 civil trials upon the consent of the litigants").

${ }^{3}$ Pub. L. No. 96-82, 93 Stat. 643 (codified as amended at 28 U.S.C. $\$ \S 631-639$ (1982)).

${ }^{6} .28$ U.S.C. $\S 636(\mathrm{c})(1)$ (1982); 18 U.S.C. $\$ 3401$ (1982). The two conditions mentioned are both necessary to allow magistrate adjudication: the district judge must refer the case to 
entry as final decisions of the district courts. ${ }^{7}$ Magistrates' decisions may be reported, and thus may carry precedential force in future litigation. ${ }^{8}$ In sum, magistrates now exercise the key powers of district court judges: they decide motions, take evidence, instruct juries, and render final decisions. ${ }^{9}$

Although federal magistrates now exercise authority similar to that of federal judges, they are not granted the tenure or salary protections of article III of the Constitution. Magistrates are appointed for limited terms, ${ }^{10}$ and can be removed by the district court judges whom they serve. A statute protects their salaries from diminution during their terms, ${ }^{11}$ but no constitutional barrier prevents Congress from eliminating this protection. Furthermore, unlike federal judges, magistrates are appointed not by the President with the advice and consent of the Senate, but by the judges of the district in which the magistrate will operate. ${ }^{12}$

When Congress adopted the 1979 Act, most observers thought that the enlarged power of magistrates did not violate article III. ${ }^{13}$ Courts began to consider the question only after Northern Pipeline Construction Co. v. Marathon Pipe Line Co. ${ }^{14}$ in which the Supreme Court struck down Congress's broad delegation of juris-

the magistrate and the parties must consent to the reference. 28 U.S.C. $\S 636(c)(1)(1982)$; see also FED. R. Crv. P. 73 (allowing federal courts to refer cases to magistrates in accordance with section $636(\mathrm{c}))$.

728 U.S.C. $\$ 636(c)(3)(1982)$.

See infra note 118.

- Once a case is delegated to the magistrate, only two elements distinguish the magistrate from the federal judge. First, the magistrate does not have the power to punish for civil or criminal contempt. 28 U.S.C. $\$ 636(\mathrm{e})$ (1982). Second, the case before the magistrate may be removed to the district court upon motion of the court or "under extraordinary circumstances shown by any party." Id. §636(c)(6).

${ }^{10}$ Id. $\S 631(\mathrm{e})$. Full-time magistrates are appointed for eight-year terms; part-time magistrates are appointed only for four-year terms. Id.

11 Id. $\$ 634(\mathrm{~b})$.

12 Compare id. $\$ 631$ (a) (appointment of magistrates) with 28 U.S.C. $\$ 133$ (1982) (appointment of district court judges).

13 See, e.g., S. REP. No. 74, 96th Cong., 1st Sess. 4 (1979), reprinted in 1979 U.S. CodE Cong. \& AD. News 1469, 1473 [hereinafter cited as Senate REPoRT]; H.R. REP. No. 287, 96th Cong., 1st Sess. 9 (1979) [hereinafter cited as HouSE REPORT]; McCabe, supra note 4, at 400. This view was by no means universal. See, e.g., House REpoRT, supra, at 31 (dissenting views of Hon. Elizabeth Holtzman); Note, Article III Limits on Article I Courts: The Constitutionality of the Bankruptcy Court and 1979 Magistrate Act, 80 CoLuM. L. Rev. 560, 583 (1980) [hereinafter cited as Note, Article I Courts]; Note, Article III Constraints and the Expanding Civil Jurisdiction of Federal Magistrates: $A$ Dissenting View, 88 YaLE L.J. 1023 (1979); see also Note, The Validity of United States Magistrates' Criminal Jurisdiction, 60 VA. L. REv. 697 (1974).

14458 U.S. 50 (1982). 
diction to bankruptcy courts. ${ }^{15}$ Since then, ten federal courts of appeals have ruled that the delegation of final decisionmaking powers to magistrates is consistent with article III. ${ }^{16}$ Indeed, one circuit recently found an attack on the constitutionality of the 1979 Act "frivolous" and assessed attorneys' fees against the appellant.17

Despite this "unbroken phalanx" of authority, ${ }^{18}$ the Act's constitutionality should not be considered settled. This comment contends that the delegation of final decisionmaking authority to magistrates violates the text and purposes of article III. Part I explains how and why article III limits Congress's power to vest judicial decisionmaking authority. It outlines the two categories of exceptions to article III's tenure and salary provisions developed by the Supreme Court, and describes the two models for interpreting the purpose of article III that have been expressed in the Court's opinions. Part II compares magistrate adjudication and the recognized exceptions to article III requirements, concluding that they do not coincide. Part III discusses whether the magistrates' exercise of judicial power is nonetheless consistent with the underlying purposes of article III. This part concludes that under neither of the Court's approaches to article III can the constitutionality of magistrate adjudication be defended. Despite the attractiveness of magistrate adjudication as an alternative to increasingly time-consuming and expensive adjudication by federal district court judges, the powers

15 See Bankruptcy Act of 1978 , Pub. L. No. $95-598,92$ Stat. 2549 (codified at 28 U.S.C. $\$ \S 1471-1482$ (1982)) (repealed by Bankruptcy Amendments and Federal Judgeship Act of 1984, Pub. L. No. 98-353, 98 Stat. 343).

${ }_{18}$ Goldstein v. Kelleher, 728 F.2d 32 (Ist Cir.), cert. denied, 105 S. Ct. 172 (1984); Collins v. Foreman, 729 F.2d 108 (2d Cir.), cert. denied, 105 S. Ct. 218 (1984); WhartonThomas v. United States, 721 F.2d 922 (3d Cir. 1983); Gairola v. Virginia, 753 F.2d 1281 (4th Cir. 1985); Puryear v. Ede's Ltd., 731 F.2d 1153 (5th Cir. 1984); Geras v. Lafayette Display Fixtures, Inc., 742 F.2d 1037 (7th Cir. 1984); Lehman Brothers Kuhn Loeb, Inc. v. Clark Oil Refining Corp., 739 F.2d 1313 (8th Cir. 1984) (en banc); Pacemaker Diagnostic Clinic of Am., Inc. v. Instromedix, Inc., 712 F.2d 1305 (9th Cir.), withdrawn and reh'g granted, 718 F.2d 971 (9th Cir. 1983), rev'd, 725 F.2d 537 (9th Cir.) (en banc), cert. denied, 105 S. Ct. 100 (1984); Fields v. Washington Metropolitan Area Transit Auth., 743 F.2d 890 (D.C. Cir. 1984); D.L. Auld Co. v. Chroma Graphics Corp., 753 F.2d 1029 (Fed. Cir. 1985).

Since Northern Pipeline, commentators have taken different positions on the constitutionality of the 1979 Magistrate Act. Compare Note, United States Magistrates Hearing Civil Cases: The Constitutionality of Rendering Final Judgments After Northern Pipeline Construction Co. v. Marathon Pipe Line Co., 59 Notre Dame L. Rev. 897 (1984) (arguing in favor of constitutionality), and Note, Federal Magistrates and the Principles of Article III, 97 Harv. L. Rev. 1947 (1984) (same), with Comment, Is the Federal Magistrate Act Constitutional After Northern Pipeline?, 1985 ARIz. ST. L.J. 189 (arguing against constitutionality).

17 D.L. Auld v. Chroma Graphics Corp., 753 F.2d 1029, 1033 (Fed. Cir. 1985).

${ }^{18}$ Geras v. Lafayette Display Fixtures, 742 F.2d 1037, 1045 (7th Cir. 1984) (Posner, J., dissenting). 
given to magistrates by the 1979 Act exceed those which Congress may grant to non-article III officials.

\section{Article III as a Limit on Congressional Grants of Adjudicatory Power}

Article III of the Constitution defines the contours of the federal judiciary. It both grants certain powers to the judicial branch and describes the manner in which those powers may be exercised. The text of article III is clear as to how the judicial power is to be exercised. But while the scope of the judiciary's powers is indicated in a description of the classes of cases to which the "judicial Power of the United States" extends, ${ }^{19}$ article III nowhere defines the troublesome concept of "judicial Power." Even though article III purports to establish a discrete category of governmental power, it provides no clear dividing line between constitutional and unconstitutional restrictions or expansions of the judicial realm.

\section{A. Article III's Tenure and Salary Provisions}

Article III, section 1 of the Constitution provides that

[t]he judicial Power of the United States shall be vested in one supreme Court and in such inferior Courts as the Congress shall from time to time ordain and establish. The Judges, both of the supreme and inferior Courts, shall hold their Offices during good Behaviour, and shall, at stated Times, receive for their Services, a Compensation, which shall not be diminished during their Continuance in Office. ${ }^{20}$

This language requires Congress to provide judges with undiminishable compensation and tenure during "good Behaviour" whenever it creates an inferior court that exercises the "judicial Power of the United States." ${ }^{21}$ Thus, the framers left Congress free to de-

10 U.S. Const. art. III, § 2, cl. 1:

The judicial Power shall extend to all Cases, in Law and Equity, arising under this Constitution, the Laws of the United States, and Treaties made, or which shall be made, under their Authority;-to all Cases affecting Ambassadors, other public Ministers and Consuls; - to all Cases of admiralty and maritime Jurisdiction;--to Controversies to which the United States shall be a Party;- to Controversies between a State and Citizens of another State;-between Citizens of different States;-between Citizens of the same State claiming Lands under Grants of different States, and between a State, or the Citizens thereof, and foreign States, Citizens or Subjects.

${ }^{20}$ Id. art. III, § 1 .

${ }^{21}$ Northern Pipeline, 458 U.S. at 59. The term "good Behaviour" has long been interpreted to mean life tenure, with removal only under the impeachment standard of article II, § 4. See, e.g., O'Donoghue v. United States, 289 U.S. 516, 529-530 (1933). 
fine the role of the "inferior" federal courts, but restricted its ability to define the institutional character of those courts. ${ }^{22}$

These restrictions on Congress protect judicial independence and impartiality. Judges who exercise "judicial Power" are not to be subjected to influence through manipulation of their tenure or salary. ${ }^{23}$ Such influence is undesirable for several reasons, relating to both the substantive protections of the Constitution and the structure of the government it establishes.

First, an independent judiciary is necessary to protect individual rights. Constitutional rights by definition transcend the political compromises of the day; only judges insulated from the formal political process can preserve those rights against popular causes. ${ }^{24}$ Thus, independent judges help assure to all citizens the enjoyment of rights and liberties granted by the Constitution.

Second, an independent judiciary is essential to the underlying structure of government created by the Constitution. Federal power is dispersed among separate branches in order to avoid political domination by any particular group. A system of checks and balances supplements this division by arming each branch against encroachment of its power by the other branches. ${ }^{25}$ Within this system, the tenure and salary requirements of article III protect the judiciary from domination by the executive branch or the legislature. If the President or Congress were to have the power to appoint judges for limited terms or to reduce judges' salaries, there would be a danger that the judiciary would merely present the views of the branch controlling it. ${ }^{26}$

${ }^{22}$ See Northern Pipeline, 458 U.S. at 64 n.15.

${ }^{23}$ The Constitutional Convention rejected a proposal to allow removal of judges by the executive and legislative branches. See 2 Max Farrand, The Records of the Federal Convention of 1787, at 428-29 (1911); P. Bator, P. Mishkin, D. Shapiro \& H. Wechsler, Hart and Wechsler's The Federal Courts and the Federal System 7 (2d ed. 1973). As Alexander Hamilton said: "Periodical appointments, however regulated, or by whomsoever made, would in some way or other, be fatal to [the courts'] necessary independence." THE FEDERALIST No. 78, at 471 (A. Hamilton) (C. Rossiter ed. 1961).

24 The Supreme Court has stated emphatically that the "primary purpose" of the salary protections is "to promote that independence of action and judgment which is essential to the maintenance of the guaranties, limitations and pervading principles of the Constitution and to the administration of justice without respect to persons and with equal concern for the poor and the rich." Evans v. Gore, 253 U.S. 245, 253 (1920).

2s See generally The Federalist No. 51 (J. Madison) (discussing checks and balances in the Constitution).

28 As the Court recently stated: "A Judiciary free from control by the Executive and Legislature is essential if there is a right to have claims decided by judges who are free from potential domination by other branches of government." United States v. Will, 449 U.S. 200, 217-218 (1980); see also Palmore v. United States, 411 U.S. 389, 413 (1973) (Douglas, J., dissenting); O'Donoghue v. United States, 289 U.S. 516, 531 (1933). 
Third, an often overlooked component of judicial independence is that article III also protects judges from control by other judges. ${ }^{27}$ Undue influence from within the judicial branch would be a serious obstacle to unbiased adjudication. ${ }^{28}$ Salary and tenure protections are necessary if judges are to decide facts and interpret the law in accordance with their own beliefs despite opposition or even ridicule from their colleagues. ${ }^{29}$

Fourth, an independent judiciary plays a vital role in regulating the federal government's relationship with the states. Article III was drafted and considered amid considerable distrust of federal power ${ }^{30}$ In particular, the states hoped to avoid a federal judiciary deferential to the wishes of the President and Congress, especially since the federal judiciary was to be granted jurisdiction over cases involving state law or with states as parties. ${ }^{31}$ By insulating the federal judiciary from external influence, the tenure and salary provisions in article III prevent presidential or congressional incursions on state sovereignty under the guise of judicial decision.

Finally, judicial independence fortifies the judiciary itself. Life tenure and undiminishable compensation increase public confidence in judicial decisions. ${ }^{32}$ These protections also help to ensure the continued attraction of qualified candidates to the federal bench. ${ }^{33}$

The values underlying article III's tenure and salary protec-

${ }_{27}$ See, e.g., Chandler v. Judicial Council, 398 U.S. 74, 84 (1970); id. at 136-37 (Douglas, J., dissenting); id. at 141-42 (Black, J., dissenting); Hastings v. Judicial Conference, 770 F.2d 1093, 1106-07 (D.C. Cir. 1985) (Edwards, J., concurring).

${ }^{28}$ During the debates of the Virginia state convention of 1829-1830, Chief Justice Marshall asked: "Is it not, to the last degree important, that [the judge] should be rendered perfectly and completely independent, with nothing to influence or control him but God and his conscience?" See O'Donoghue v. United States, 289 U.S. 516, 532 (1933) (quoting Marshall's statement).

29 See Kaufman, Chilling Judicial Independence, 88 YaLE L.J. 681, 714 (1979); Note, Article I Courts, supra note 13, at 583-84.

so Indeed, some states did not want lower federal courts at all. The Constitution thus allows Congress to decide whether to establish them. See 1 The Records of the Federal Convention of 1787, at 124-25 (M. Farrand rev. ed. 1937); Charles Wright, The Law of Federal Courts 2 (4th ed. 1983).

31 See Raoul Berger, Congress v. the Supreme Court 8, 117-19 (1969); Tushnet, Invitation to a Wedding: Some Thoughts on Article III and a Problem of Statutory Interpretation, 60 Iowa L. Rev. 937, 944 (1975); Note, Article I Courts, supra note 13, at 583. Judge Posner has noted that "[t]he states have not consented to have issues of their own law determined by judges who do not have the guarantees of independence that Article III requires for federal judges." Geras v. Lafayette Lighting Fixtures, 742 F.2d 1037, 1052 (7th Cir. 1984) (Posner, J., dissenting).

32 Northern Pipeline, 458 U.S. at 59 n.10; Note, Article I Courts, supra note 13, at 583.

${ }^{33}$ See O'Donoghue v. United States, 289 U.S. 516, 533 (1933). 
tions represent the stakes in the controversy about the constitutionality of magistrate adjudication. If magistrates exercise the "judicial Power" of the United States, then their lack of article III protection will undermine these values.

\section{B. Exceptions to the Rule: Delegation of Adjudicatory Powers to Non-Article III Officials}

The Supreme Court has acknowledged two situations in which Congress can create adjudicatory institutions whose officials lack the tenure and salary protections of article III: Congress can grant to legislative courts jurisdiction over certain matters to which the "judicial Power of the United States" also extends, and it can assign certain functions ordinarily performed by article III judges to adjunct officers of the federal courts.

1. Delegation of Jurisdiction to Legislative Courts. Although article III, section 2 describes the cases to which the judicial power of the United States extends, ${ }^{34}$ it does not give the federal judiciary exclusive power to adjudicate such cases. ${ }^{35}$ Other institutions acting under different sources of authority-state courts, for example-may also exercise jurisdiction over matters enumerated in section 2 without being considered article III courts. Likewise, article III protection need not be extended to certain congressionally created courts even though they decide cases within the realm of federal judicial power. ${ }^{36}$

${ }^{34}$ U.S. Consr. art. III, $\& 2$, cl. 1 .

35 The Court has long recognized that non-article III courts may be granted jurisdiction over cases to which article III judicial power clearly extends. See Northern Pipeline, 458 U.S. at 63 n.14; Palmore v. United States, 411 U.S. 389, 402 (1973); Williams v. United States, 289 U.S. 553, 566 \& n.1 (1933). Similarly, when Congress creates an article III court it need not confer on it all the jurisdiction granted by article III, $\$ 2$. Glidden Co. v. Zdanok, 370 U.S. 530,561 (1955).

${ }^{36}$ See, e.g., Northern Pipeline, 458 U.S. at 63-70; American Ins. Co. v. Canter, 26 U.S. (1 Pet.) 511, 545-46 (1828).

There have been two approaches to the question of why legislative courts do not need to meet article III's requirements. The first argues that legislative courts, because they were created under Congress's article I or article IV powers, do not exercise article III judicial power, and thus need not meet article III's requirements. See, e.g., Canter, 26 U.S. (1 Pet.) at 545 (the jurisdiction of the territorial courts "is not a part of that judicial power which is defined in the $3 \mathrm{~d}$ article of the Constitution"); United States ex rel Toth v. Quarles, 350 U.S. 11, 13-14 (1955) (military courts' jurisdiction is limited because Congress's article I powers over the military are limited). The second, which Justice White seemed to follow in Northern Pipeline, argues that legislative courts do exercise "judicial Power," but are exempted from article III's requirements. See Northern Pipeline, 458 U.S. at 105 (White, J., dissenting) (rejecting proposition that legislative courts do not exercise article III power). In essence, these approaches are the same; under both the legislative courts are exempted from article III because they were created under article I or article IV congressional powers. 
The Supreme Court has permitted such "legislative courts" in three separate situations. First, the Court has allowed Congress to create non-article III courts to serve the territories of the United States. Because the territorial courts ostensibly were created under article IV, which grants Congress plenary authority over the territories, and not under article III, they were found not to be subject to article III's tenure and salary restrictions. ${ }^{37}$ The Court has upheld the creation of military courts for a similar reason. Article I empowers Congress to "provide and maintain a Navy"38 and to make "Rules of the Government and Regulation of the land and naval Forces." 39 On this basis, Congress's power to establish special courts for the trial and punishment of military offenses is "without any connection" to and "entirely independent" of article III. ${ }^{40}$ And lastly, the Court has approved Congress's creation of non-article III courts for the adjudication of "public rights."41 This category includes matters historically within the prerogative of the executive or legislative branches and that could have been completely committed to non-judicial determination. ${ }^{42}$

Under either approach, the key jurisdictional inquiry is whether Congress has created these courts under its power to create "inferior" article III courts, or under some other power.

${ }^{37}$ Canter, 26 U.S. (1 Pet.) at 545. The Court followed the same reasoning in allowing Congress to create territorial legislative courts in the District of Columbia, see Kendall v. United States, 37 U.S. (12 Pet.) 524 (1838), in the Indian territories, see Wallace v. Adams, 204 U.S. 415, 423 (1907), and in the consular territories abroad, see In re Ross, 140 U.S. 453 (1891).

38 U.S. ConsT. art. I, \& 8, cl. 13.

30 Id. art. I, \& 8, cl. 14 .

10 Dynes v. Hoover, 61 U.S. (20 How.) 65, 79 (1857). In subsequent decisions, however, the Court has limited the jurisdiction of courts martial so as not to encroach upon matters otherwise outside the realm of the military. See United States ex rel. Toth v. Quarles, 350 U.S. 11 (1955) (the jurisdiction of the military court does not extend to the trial of a recently discharged civilian even though his offense was committed during active service).

${ }^{4}$ See Murray's Lessee v. Hoboken Land \& Improvement Co., 59 U.S. (18 How.) 272, 284 (1856) ("there are matters, involving public rights, . . . which are susceptible of judicial determination, but which congress may or may not bring within the cognizance of the courts of the United States"); see also Ex parte Bakelite Corp., 279 U.S. 438, 458 (1929). In contrast, other "inherently" judicial matters may not be removed from the cognizance of the article III courts: Congress cannot "withdraw from [art. III] judicial cognizance any matter which, from its nature, is the subject of a suit at the common law, or in equity, or admiralty." Murray's Lessee, 59 U.S. (18 How.) at 284.

12 The Court originally relied upon a "public rights" rationale in approving Congress's creation of such legislative courts as the Court of Customs and Patent Appeals, see Ex parte Bakelite Corp., 279 U.S. 438 (1929), and the Court of Claims, see Williams v. United States, 289 U.S. 553 (1933). Both cases dealt with courts exclusively hearing suits "between the government and others." Bakelite, 279 U.S. at 451 . Both of these courts have since been ruled article III courts. See Glidden Co. v. Zdanok, 370 U.S. 530 (1962) (noting that subsequent legislation indicated Congress's intent to create these courts under its article III power). The "public rights" doctrine has also been invoked to allow Congress to vest adjudi- 
The Supreme Court addressed the constitutional status of legislative courts in its 1983 decision, Northern Pipeline Construction Co. v. Marathon Pipe Line Co. ${ }^{43}$ In Northern Pipeline the Court considered whether Congress could grant to non-article III bankruptcy courts jurisdiction over "all civil proceedings arising under title 11 [of the United States Code] or arising in or related to cases under title 11."44 Justice Brennan, in a plurality opinion, rejected the claim that the bankruptcy courts were legislative courts created under Congress's article I power to establish "uniform Laws on the subject of Bankruptcies." ${ }^{\text {"45 }}$ Instead he argued that Congress's power to create legislative courts was limited to the three historically accepted categories of cases discussed above, all of which stemmed from "exceptional constitutional grants of power" to Congress. ${ }^{46}$ Despite their tie to an enumerated article I power, the bankruptcy courts did not fall into any of the three categories, particularly because the bankruptcy courts exercised jurisdiction over claims relating to bankruptcy but arising entirely under state or common law. 47

In a concurring opinion, Justice Rehnquist declined to decide whether Congress's grant of jurisdiction to the bankruptcy courts as a whole violated article III. ${ }^{48}$ Instead, he limited his decision, and thus the decision of the Court, to the holding that the jurisdiction of non-article III courts could not, absent litigant consent, extend to cases arising entirely under state or common law. To the extent that the Bankruptcy Act granted such jurisdiction, it violated article III. ${ }^{49}$

The Court returned to the question of legislative courts in Thomas v. Union Carbide Agricultural Products Co. ${ }^{50}$ Union Car-

catory powers in administrative agencies. See Atlas Roofing Co. v. Occupational Safety \& Health Review Comm'n, 430 U.S. 442, 450 (1977); Crowell v. Benson, 285 U.S. 22, 50 (1932). The Court's most recent statement on the "public rights" doctine was in Thomas v. Union Carbide Agricultural Prods. Co., 105 S. Ct. 3325 (1985), discussed infra notes 50-54 and accompanying text.

43458 U.S. 50 (1982).

1128 U.S.C. \& 1471(b) (1982).

15 U.S. Const. art. I, $\S 8$, cl. 4.

18 Northern Pipeline, 458 U.S. at 70 \& n.25.

17 Id. at 71-76.

${ }^{4}$ Id. at 89 (Rehnquist, J., concurring).

49 Id. at 91. In Thomas, $105 \mathrm{~S}$. Ct. at 3334-35, a majority of the court characterized the Northern Pipeline holding as follows: "Congress may not vest in a non-Article III court the power to adjudicate, render final judgment, and issue binding orders in a traditional contract action arising under state law, without consent of the litigants, and subject only to ordinary appellate review."

so 105 S. Ct. 3325 (1985). 
bide challenged the constitutionality of a federal product registration program in which certain claims between private registrants were subjected to binding arbitration by an independent, non-article III decisionmaker. ${ }^{51}$ In approving the scheme, the Court emphasized that Northern Pipeline stood only for the proposition that Congress may not empower non-article III officers to adjudicate issues of state law without the parties' consent. ${ }^{52}$ The Court held that the arbitration scheme challenged in Thomas did not fall within that prohibition: the arbitrable claims involved rights which more closely resembled public than private rights. Since these "public rights" issues "could be conclusively determined by the Executive and Legislative Branches," ticle III officers carries little threat to "the independent role of the judiciary in our constitutional scheme."34

Northern Pipeline and Thomas do not definitively determine the full extent of Congress's power to delegate judicial power to non-article III legislative courts. They do, however, provide some insight into the relationship between article III and the power to create legislative courts. First, and most important, a majority of the Court in Northern Pipeline acknowledged that the power to create non-article III legislative courts is in fact limited by article III. Before Northern Pipeline, the Court had never struck down a congressional grant of power to what was arguably a legislative court on the grounds that it violated article III. ${ }^{55}$ Second, both decisions suggest that there is a "core" of federal jurisdiction which in some instances Congress may not delegate to officials who lack tenure and salary protection. Even under the potentially expansive "public rights" doctrine, Congress is limited in its power to delegate to non-article III courts jurisdiction over common law and

s1 Id. at 3328-30. Under the Federal Insecticide, Fungicide, and Rodenticide Act, 7 U.S.C. $\$ \S 136-136(y)$ (1982), pesticide manufacturers wishing to register their products are required to submit research data concerning the effects of their products to the Environmental Protection Agency. Id. $\S 136 \mathrm{a}(\mathrm{c})(1)(\mathrm{D})$. If more than one manufacturer seeks to register a given product, EPA may use the data provided by an earlier registrant to evaluate the product of a later registrant. Id. The Act requires that the later registrant compensate the earlier registrant for use of the data. If the parties cannot agree on compensation, the Act requires that the dispute be decided through private arbitration. The arbitrator's decision is binding, and is reviewable in an article III court only for "fraud, misrepresentation or other misconduct." Id. § 136a(c)(1)(D)(ii).

s2 $105 \mathrm{~S}$. Ct. at 3334-35.

ss Id. at 3334 .

s. Id. at 3338.

ss The Court has in the past restricted the jurisdiction of the legislative courts, but never struck down the underlying statute as unconstitutional. See, e.g., United States ex rel. Toth v. Quarles, 350 U.S. 11 (1955). 
state law matters.

2. Delegation of Adjudicatory Functions to Court Adjuncts. It has long been established that not all adjudicatory functions in federal courts must be performed by article III judges. ${ }^{56}$ Courts, particularly those sitting in equity, traditionally have appointed judicial "adjuncts" to perform particular functions for the court. In theory, this kind of delegation, unlike the delegation of jurisdiction to legislative courts, is a delegation entirely within the judicial branch; the adjunct's power derives from the article III court, in which jurisdiction and control remain vested..$^{57}$ For example, masters and commissioners have long aided judges by taking testimony, identifying the questions at issue, and making preliminary determinations of fact. ${ }^{58}$ Their proceedings were subject to the direction of the court and their findings, at least as to matters of law, were essentially advisory. ${ }^{50}$

Despite the longstanding use of adjuncts, few Supreme Court decisions have tested the constitutional limits to their use. The

${ }^{58}$ The seventh amendment's requirement of trial by jury, for example, delegates decisionmaking authority to juries. See Crowell v. Benson, 285 U.S. 22, 51 (1932).

${ }^{57}$ The Iower courts' power to delegate authority to masters or referees arises out of a long common law tradition of such subordinate judicial officers. See generally Silberman, Masters and Magistrates Part I: The English Model, 50 N.Y.U. L. REv. 1071 (1975) [hereinafter cited as Silberman, The English Model]; Silberman, Masters and Magistrates Part II: The American Analogue, 50 N.Y.U. L. REv. 1297 (1975). The use of masters in federal court in the United States has been described as "coeval with the organization of our judicial system." Heckers v. Fowler, 69 U.S. (2 Wall.) 123, 128 (1864); see also Crowell v. Benson, 285 U.S. 22, 51-52 (1932) (parties have no right to demand that a court disturb the findings of a master absent an error of law). The practice of referring cases to masters with the consent of the parties was mentioned by the Court as early as 1810. See Field v. Holland, 10 U.S. (6 Cranch) 8, 21 (1810); see also Alexandria Canal Co. v. Swann, 46 U.S. (5 How.) 82, 90 (1847) ("it is now well settled . . . that the appointment [of an umpire] is good"). The Court explicitly approved lower court delegation of certain functions to adjunct officers regardless of the consent of the parties in Ex parte Peterson, 253 U.S. 300, 314 (1920) (approving the appointment of an auditor to frame the issues and express an opinion).

Congress's power to create adjunct officers of the federal courts arises as a "necessary and proper" corollary to its power to create inferior federal courts. U.S. CoNST. art. I, § 8, cl. 9 ("The Congress shall have Power ... [t]o constitute Tribunals inferior to the supreme Court."). When "viewed within the entire judicial framework set up by Congress," delegation of limited adjudicatory functions to adjuncts seems consistent with the principle that the judicial power of the United States be vested in article III courts. Northern Pipeline, 458 U.S. at 76-77.

${ }^{\circ 8}$ See generally Silberman, The English Model, supra note 57 (describing operation of English master system).

s9 See Crowell v. Benson, 285 U.S. 22, 61 (1932); Kimberly v. Arms, 129 U.S. 512, 523 (1889); Heckers v. Fowler, 69 U.S. (2 Wall.) 123, 133 (1864). For the current rules governing use of masters, see FED. R. Crv. P. 53; see also La Buy v. Howes Leather Co., 352 U.S. 249 (1957) (discussing references to masters under rule 53(b)). 
first case to address the issue, Crowell v. Benson, ${ }^{60}$ considered Congress's power to delegate judicial functions to a non-article III administrative agency, the United States Employees' Compensation Commission. ${ }^{61}$ In Crowell, the Court tested the constitutionality of the adjunct delegation by looking at whether it deprived article III courts of the "essential attributes" of judicial power. ${ }^{62}$ Delegating general fact-finding authority to an administrative agency was acceptable for the same reasons special masters or commissioners could assist courts in admiralty: the court retained all power over questions of law, the agency's power was limited by statute to a narrow range of factual questions, and the agency's orders could not be enforced except by order of the district court. ${ }^{63}$ But vesting the agency with the power to determine facts of constitutional importance, such as whether or not the case fell within the federal admiralty jurisdiction, would rob the court of the "essential attributes" of judicial power and would thus not be permitted by article III. ${ }^{64}$

In United States v. Raddatz ${ }^{65}$ the Supreme Court applied the "essential attributes" standard to the 1976 Magistrates Act. The Court upheld Congress's delegation to magistrates of the authority

o 285 U.S. 22 (1932).

61 The Court in Crowell did not define administrative decisionmakers as "adjuncts." The Court did, however, analogize to traditional adjuncts, $i d$. at 51, and Justice Brennan later analyzed Crowell as an adjuncts case, Northern Pipeline, 458 U.S. at 78 ("The use of administrative agencies as adjuncts was first upheld in Crowell."). Although the agency's power was based on federal statutes defining congressionally created rights, the Court rejected a "legislative courts" analysis because the rights involved were essentially "private rights" arising under the admiralty jurisdiction of article III. Crowell, 285 U.S. at 51. The Court defined an issue of private right as one "of the liability of one individual to another under the law as defined." Id.

2285 U.S. at 51.

6s Id. at $44-45,54$.

"I Id. at 56-57. The statutory scheme in Crowell withstood the "essential attributes" analysis because certain "constitutional facts," especially those relating to the agency's jurisdiction, were to be decided de novo by the federal court without deference to the agency's findings. Id. at 63-64. The agency's power to decide other facts, however, was not limited by article III since "there is no requirement that, in order to maintain the essential attributes of the judicial power, all determinations of fact in constitutional courts shall be made by judges." Id. at 51; see supra note 57.

The Court's emphasis on the distinction between "constitutional" and other facts was diminished in St. Joseph Stock Yards Co. v. United States, 298 U.S. 38, 53 (1936), where the Court stated that "th[e] judicial duty to exercise an independent judgment does not require or justify disregard of the weight" of administrative findings. Although St. Joseph involved the requirements of the due process clause rather than those of article III, its challenge to Crowell's de novo review requirement has been adopted in article III cases. See, e.g., United States v. Raddatz, 447 U.S. $667,682-683$ (1980).

os 447 U.S. 667 (1980). 
to hear certain dispositive pretrial motions on the grounds that the district court maintained sufficient control over the proceedings. ${ }^{66}$ The statutory scheme at issue in Raddatz gave the district court "plenary discretion" to decide whether to authorize a magistrate hearing and automatically subjected the magistrate's findings to de novo review by the district court. In light of this, the Court found that the magistrate's power did not remove the "ultimate decision" from the district judge, and thus left the "essential attributes" of the judicial power in an article III court. ${ }^{67}$

The Court last discussed adjuncts in Northern Pipeline. In his plurality opinion, Justice Brennan reiterated the test of Crowell and Raddatz: ${ }^{68}$ although Congress can prescribe the manner in which congressionally created rights can be adjudicated, it may only do so in a way which retains the "essential attributes" of judicial power in an article III court. ${ }^{69} \mathrm{He}$ then identified several ways in which the Bankruptcy Act of $1978^{70}$ impermissibly vested the essential attributes of the "judicial Power of the United States" in bankruptcy courts: first, the bankruptcy courts' jurisdiction was coextensive with that of the district courts for all matters related to bankruptcy questions; ${ }^{71}$ second, bankruptcy courts exercised all the ordinary powers of the district courts, including the power to conduct jury trials and to issue declaratory judgments, writs, and orders; ${ }^{72}$ third, the bankruptcy courts issued binding and enforcea-

${ }^{68}$ Raddatz dealt with the judge's treatment of a magistrate's recommended decision on a motion to suppress evidence. Much of the case considered the due process aspects of the judge's review of the magistrate's recommendations. See 447 U.S. at 679-681.

${ }^{67}$ Id. at 683 (quoting Mathews v. Weber, 423 U.S. 261, 275 (1976)). On the same grounds, the Court rejected petitioner's due process objections to the handling of pretrial hearings by magistrates: the article III judge remained the "ultimate decisionmaker," with "broad discretion to accept, reject-or modify the magistrate's proposed findings." Id. at 680 . The district judge read over the testimony transcript and the magistrate's report and listened to oral argument before making the final decision. Id. at 672 .

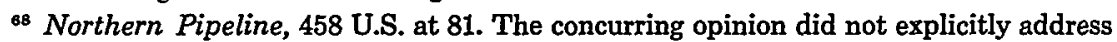
the question, except to say that the bankruptcy courts clearly were not "adjuncts" of the district courts. Id. at 91 (Rehnquist, J., concurring). Justice White objected to the plurality's analysis on the grounds that it failed to rationalize why the Raddatz test represents the constitutional limit. Id. at 101 (White, J., dissenting).

${ }^{6 \theta} I d$. at 81 (plurality opinion). In Crowell, the district court retained full authority over matters of law, 285 U.S. at 49; in Raddatz, the court retained power to review the magistrate's findings and make the ultimate decision before entry of judgment, 447 U.S. at 683.

70 Pub. L. No. 95-598, 92 Stat. 2549 (codified as amended at 28 U.S.C. $\S \S 1471-1482$ (1982)).

71 Northern Pipeline, 458 U.S. at 85.

72 Id. 
ble final judgments. ${ }^{73}$ Given these powers, the bankruptcy courts were not "adjuncts," but rather entities independent in jurisdiction and function from any article III court, and hence unconstitutional. ${ }^{74}$

These cases stand for the proposition that adjunct adjudication cannot preclude an article III court from making the final determination of certain issues. In other words, the "essential attributes" of the judicial power must remain with the article III court. In Crowell, Congress did not remove the essential attributes of judicial power from article III courts because courts retained full power to review agency determinations of questions of law and of certain questions of fact. The scheme in Raddatz survived because magistrate decisions were essentially advisory and did not constitute final determinations.

C. The Scope of the Exceptions: Competing Views of Article III

Although the Supreme Court has identified two different categories of cases in which Congress can delegate judicial decisionmaking powers to non-article III officials, it has never precisely defined the scope of those categories. It may be possible, then, to defend the Magistrate Act in any of three ways: as fitting within narrow definitions of the categories; as fitting within expansive definitions of the categories; or as an independent exception to article III's tenure and salary requirements. Which approach a court takes depends fundamentally upon its view of the meaning of article III.

The Court's decisions, particularly those dealing with the creation of legislative courts, reveal two competing approaches to article III. ${ }^{75}$ The first approach, most recently expressed by Justice Brennan in his plurality opinion in Northern Pipeline, might be termed the "constitutional principles" approach. Under this conception of article III, Congress must comply with the tenure and salary restrictions whenever it establishes an institution that exercises the "judicial Power of the United States."76 Congress need

73 Id. at 85-86.

34 Id. at 87.

${ }^{75}$ The two approaches considered here have been developed in the context of the Court's decisions on the constitutionality of the various legislative courts. They are equally applicable, however, in the context of limitations on Congress's power to create adjuncts. In both situations, the essential question is to what extent article III prevents Congress from creating adjudicatory institutions or officers not subject to that article's tenure and salary provisions.

${ }_{76} 458$ U.S. at 58-59; see also Palmore v. United States, 411 U.S. 389, 420 (1973) (Douglas, J., dissenting) ("If the power exercised is 'judicial power' defined in Art. III . . . then 
not do so if the decisionmaking institution it creates merely exercises adjudicative power derived from other sources, such as Congress's article I authority. ${ }^{77}$ It is for the Court to determine the nature and source of the jurisdiction exercised by the decisionmaker-a determination that is not to rest upon congressional intent. ${ }^{28}$

It might be argued that the "constitutional principles" approach amounts to little more than a labeling process: ${ }^{79}$ neither the text of article III nor the Court's confusing precedents provide a test for determining whether a particular court or official exercises "the judicial Power of the United States." The approach has, however, emerged in practice as a narrow restriction on Congress's ability to create alternatives to article III adjudication. Because adjudication of matters within the constitutional scope of the judicial power by non-article III institutions is seen as a threat to the power and independence of the federal judiciary, the "constitutional principles" approach would limit encroachments to exceptional situations where non-article III adjudication is both necessary to meet unique circumstances and poses less of a threat to judicial authority. ${ }^{81}$

In contrast, the second approach to article III, which might be

the standards and procedures must conform to Art. III, one of which is an independent judiciary.").

${ }_{77}$ See, e.g., supra notes $38-40$ and accompanying text.

78 See Ex parte Bakelite Corp., 279 U.S. 438, 459 (1929); Glidden Co. v. Zdanok, 370 U.S. 530, 602-03 (1962) (Douglas, J., dissenting). But see id. at 542 (plurality opinion).

${ }^{70}$ An example of this is Glidden Co. v. Zdanok, 370 U.S. 530, 552 (1962), where Justice Harlan argued that whether a court exercises article III judicial power depends upon whether the judges of that court were endowed with lifetime tenure and undiminishable salary. See Northern Pipeline, 458 U.S. at 113 (White, J., dissenting) ("One hundred and fifty years of constitutional history . . . had led to a simple tautology."). Similarly, Justice Brennan's opinion in Northern Pipeline has been challenged for inadequately justifying its refusal to extend legislative court status to the bankruptcy courts. See 458 U.S. at 103-05 (White, J., dissenting).

${ }^{\text {so }}$ See 458 U.S. at 103-05 (White, J., dissenting). But see Currie, Bankruptcy Judges and the Independent Judiciary, 16 CREIGHTON L. REv. 441, 461 (1983) (arguing that precedent supports Brennan's approach).

81 The "constitutional principles" approach is weakened by its failure to recognize decisions of the Court which have upheld congressional grants of adjudicative authority to non-article III officials in part because of the impracticality of endowing large numbers of officials with life tenure. See, e.g., Glidden, 370 U.S. at 547 (legislative courts have been created as a result of a "confluence of practical considerations"). Thus, to the extent that it construes article III narrowly, this approach clashes with the flexibility the Court has read into article III through a long line of decisions running from American Ins. Co. v. Canter, 26 U.S. (1 Pet.) 511 (1828), to Palmore v. United States, 411 U.S. 389 (1973); see also Tushnet, supra note 31 , at 940 (the Court's precedents reduce article III limits to a requirement that congressional departures from article III be "reasonable"). 
termed the "due process" approach, is based upon the idea that Congress may grant the power to decide cases falling within the judicial power of the United States to non-article III officials so long as Congress provides institutional safeguards to preserve the values embedded in article III. This view can be seen in two recent opinions: Justice White embraced it openly in his Northern Pipeline dissent, ${ }^{82}$ and a majority of the Court appeared to use it in Thomas.

In Northern Pipeline, Justice White proposed a test that balances the burden of a particular institutional arrangement on article III values against "the values Congress hopes to serve" through the use of courts not staffed by article III officials. ${ }^{83}$ His major concern is the process by which a litigant's rights and responsibilities are adjudicated, rather than the source of a particular court's or official's power to adjudicate. Carried to an extreme, this approach suggests that article III's tenure and salary protections add little or nothing to the due process clause, ${ }^{84}$ and that article III need be followed only when "under the circumstances, the constitutional requirement of due process is a requirement of judicial process." 85

Like Justice White in Northern Pipeline, the majority in Thomas seemed to balance congressional interests against article

8245 U.S. at 115 (White, J., dissenting).

ss Id. Justice White based his position in part on a broad reading of the language of his majority opinion in Palmore v. United States, 411 U.S. 389 (1973), which stated that "the requirements of Art. III, which are applicable where laws of national applicability and affairs of national concern are at stake, must in proper circumstances give way to accommodate plenary grants of power to Congress to legislate with respect to specialized areas having particularized needs and warranting distinctive treatment," id. at 407-08; see Northern Pipeline, 458 U.S. at 114-15 (White, J., dissenting) (discussing Palmore). One commentator has suggested that Palmore stood for the proposition that the Court would allow Congress to create a legislative court whenever Congress's decision to do so was "reasonable." Tushnet, supra note 31, at 940. But in Northern Pipeline, the plurality rejected Justice White's reading of this passage and argued that the word "areas" in the above passage applied only to "geographical areas," not subject-matter areas. 458 U.S. at 76.

st U.S. CoNST. amend. V. The framers of article III clearly intended the tenure and salary provisions to limit Congress's ability to encroach on judicial power. Justice White's "due process" approach can be criticized because a balancing test could permit Congress to trump the constitutional language. Like many balancing tests, the "due process" approach may give undue weight to legislative interests like "efficiency" or "economy" at the expense of important but unquantifiable constitutional values. See, e.g., Northern Pipeline, 458 U.S. at 73,74 n.28.

ss Crowell v. Benson, 285 U.S. 22, 87 (1932) (Brandeis, J., dissenting); see Northern Pipeline, 458 U.S. at 117 (White, J., dissenting). But see Note, Article I Courts, supra note 13 , at 584-585 (arguing that due process review would be inadequate to replace the requirements of article III). Although this comment refers to this view as the "due process" approach, it does not derive from the fifth or fourteenth amendments, except by the indirect analogy made here. 
III values. The Court did examine the source of power vested in the arbitrator: it noted that questions subject to arbitration fall within the category of "public rights." did not stop with the categorical status of the arrangement. The Court also found it important that the arbitration provision served a significant legislative purpose in a larger regulatory framework. ${ }^{87}$ In addition, the Court tried to estimate the provision's potential to encroach on judicial independence: the Court found that the arbitrator was no more likely to be influenced by the political branches than was an article III judge ${ }^{88}$ and that the arbitration scheme relies "only tangentially, if at all, on the Judicial Branch for enforcement." exceptions to article III's tenure and salary protections, but also to "the concerns motivating the legislature" and the impact of the statutory scheme on "the independent role of the judiciary in our constitutional scheme." 90

The approach in Thomas, like that of Justice White in Northern Pipeline, differs from the "constitutional principles" analysis by explicitly considering a broad range of competing values, thus giving Congress greater freedom to create alternatives to article III adjudication. But the decision in Thomas indicates that the Court is not willing to abandon the "constitutional principles" inquiry into the nature and source of the non-article III institution's powers. ${ }^{91}$ Rather, the Court appears to be staking out a middle ground: the Court will ask whether a challenged institution fits within the traditional exceptions to article III's limitations, but in determining the reach of those exceptions the Court will examine whether the institution adequately accommodates article III values.

\section{Do Magistrates Exercise the "Judicial Power of the UNITED STATES?"}

Ten circuits have concluded that magistrate adjudication under the Federal Magistrate Act of 1979 does not violate article III. ${ }^{92}$ In essence, the courts have followed a pure "due process" balancing approach. They argue that although the Act delegates full

${ }^{86}$ Thomas, $105 \mathrm{~S}$. Ct. at 3337. Justice Brennan concurred in the judgment on this basis. Id. at 3343 .

${ }^{87}$ Id. at $3337-38$.

ss Id. at 3338 .

so Id.

${ }^{90}$ Id.

21 Id. at 3337.

${ }^{22}$ See supra note 16. 
adjudicatory functions to non-article III officials, which seems constitutionally suspect, it contains procedural mechanisms to protect litigant rights and the separation of powers. Because magistrates only adjudicate disputes when parties have so consented, litigants are held to have waived their right to be heard by an article III judge in the same way as they can waive the right to jury trial or the privilege against self-incrimination. ${ }^{93}$ And, because the Act gives article III judges control over magistrates-article III judges appoint magistrates, refer cases to magistrates, remove cases from magistrates in certain circumstances, and review magistrate decisions on appeal-the magistrates are thought to be adequately insulated from the influence of the legislative and executive branches. ${ }^{94}$ The Act is judged constitutional under a "due process" balancing approach since it combines an important legislative interest-reducing the federal judges' caseload-with an institutional structure that protects article III values. ${ }^{95}$

But the courts have approved of the Magistrate Act without analyzing the sources of magistrate power. Such an analysis is central to the "constitutional principles" approach, which would invalidate the Act if magistrates are found to fall outside the established exceptions to article III's tenure and salary requirements. But, as Thomas shows, the analysis is pertinent to the Court's current "due process" approach as well. ${ }^{\circ 6}$ The Act would be invalid under a Thomas-style "due process" approach if the extent of the Act's intrusion upon the "judicial Power" is not warranted by the purposes of the delegation-and the extent of that intrusion is likely to be determined at least in part by the disjunction between the delegation and the traditional exceptions of article III.97 The following discussion therefore examines whether magistrates exercise adjudicatory power either as officers of legislative courts or as

9s See, e.g., Pacemaker Diagnostic Clinic of Am., Inc. v. Instromedix, Inc., 725 F.2d 537, 543 (9th Cir.), cert. denied, 105 S. Ct. 100 (1984); Wharton-Thomas v. United States, 721 F.2d 922, 925-26 (3d Cir. 1983).

os See, e.g., Pacemaker, 725 F.2d at 545-46; Wharton-Thomas, 721 F.2d at 927.

${ }^{95}$ Contrast the majority's approach in Pacemaker, 725 F.2d at 541, 547, with that of the dissent, id. at 550 (Shroeder, J., dissenting).

os See, e.g., Thomas, $105 \mathrm{~S}$. Ct. at 3336 (using "public rights" category while rejecting "doctrinaire reliance" on formal categories), discussed supra notes 86-91 and accompanying text.

${ }^{97}$ For example, the Court has consistently held that Congress's delegation of judicial functions to non-article III courts must be tied to "exceptional constitutional grants of power to Congress." See, e.g., Northern Pipeline, 458 U.S. at 70 n.25. While Justice White appeared to abandon this principle in his dissent in Northern Pipeline, id. at 104, the approach taken by the majority in Thomas was consistent with it. $105 \mathrm{~S}$. Ct. at 3337-38 (expanding, rather than abandoning, "public rights" category). 
adjuncts of district courts. If they do not fall within these categories, then they should be seen as impermissibly exercising the "judicial Power of the United States" unless their role is validated by the "due process" approach.

\section{A. Magistrate Jurisdiction and Congress's Power to Create Legislative Courts}

One way Congress might have granted magistrates the authority to hear and decide cases falling within the federal judicial power is through its power to establish legislative courts. Much of the pre-Northern Pipeline commentary considering the Magistrate Act focused on this approach. ${ }^{88}$ But since Northern Pipeline, courts have largely rejected that approach as inapplicable to the constitutional problems posed by the Magistrate Act. ${ }^{99}$

Magistrates differ from officers of legislative courts in four major respects. First, magistrates are situated within and controlled by the judicial branch; legislative courts are not. ${ }^{100}$ Second, the magistrates' power to hear cases is triggered only on referral by the district court and consent of the parties; a legislative court's power is triggered upon the filing of the case. ${ }^{101}$ Third, the district court may remove cases from a magistrate on its own motion or on motion of the parties; ${ }^{102}$ legislative courts are only subject to appellate judicial review. Fourth, magistrates are appointed by federal judges in a process free of executive or legislative involvement; ${ }^{103}$ legislative court judges are usually appointed by the President with Senate approval. ${ }^{104}$ Because these four factors create a high degree of integration with district courts, magistrates resemble judicial adjuncts much more closely than they resemble officers of legislative courts.

Furthermore, the scope of magistrate jurisdiction under the 1979 Act exceeds that which could be vested in a legislative

${ }^{88}$ See, e.g., Note, Article I Courts, supra note 13 , at 568 \& n.62.

${ }^{80}$ See, e.g., Wharton-Thomas, 721 F.2d at 925-27.

100 For a discussion of judicial controls on magistrates, see infra notes 154-66 and accompanying text.

101 See, e.g., 42 U.S.C. $\S 405$ (b) (1982) (granting to the Administrator of the Department of Health \& Human Services the power to make disability determinations).

10228 U.S.C. $\$ 636(\mathrm{c})(6)$ (1982).

${ }^{103}$ Id. $\S 631(\mathrm{a})$.

104 E.g., 10 U.S.C. § 867(a)(1) (1982) (United States Court of Military Appeals "consists of three judges appointed from civil life by the President, by and with the advice and consent of the Senate"). 
court. ${ }^{105}$ The Supreme Court's holding in Northern Pipeline, even as limited by Justice Rehnquist's concurring opinion, ${ }^{106}$ makes clear that article III limits congressional power to grant jurisdiction to legislative courts: legislative courts cannot exercise jurisdiction over matters arising entirely under state or common law. ${ }^{\mathbf{1 0 7}}$ Those matters "may be resolved only by an agency which exercises ' $t$ t]he judicial power of the United States.' "108 Congress's power to authorize legislative courts extends only as far as "certain exceptional powers bestowed upon [it] by the Constitution or by historical consensus." 109 But the magistrates' authority is not based on any specific, exceptional power of Congress. Magistrates exercise subject-matter jurisdiction over a significant number of federal criminal matters and any federally cognizable civil matter, including cases involving non-government parties and purely private rights. Thus, even if Congress can create legislative courts within its power to prescribe the manner of adjudication for any congressionally created right-the furthest extreme suggested by Northern Pipeline ${ }^{110}$ - the magistrates' jurisdiction definitely exceeds the limits of that power.

The requirement of party consent does not make the argument that the Magistrate Act can be justified as an exercise of Congress's power to create legislative courts any less constitutionally suspect. ${ }^{111}$ In considering the subject-matter jurisdiction of article III courts, the Supreme Court has emphasized that litigant consent cannot substitute for constitutional power. ${ }^{112}$ Analogously,

105 The magistrates' jurisdiction also could not be vested in an administrative agency, since even under Justice Brennan's expansive characterization of agencies as adjuncts in Northern Pipeline, agencies are still restricted to "specialized" functions. 458 U.S. at 80 n.32.

${ }^{106}$ See id. at 89-92 (Rehnquist, J., concurring).

${ }^{107}$ Id. at 90; see also Thomas, 105 S. Ct. at 3334-35.

108458 U.S. at 89. The same basic view was expressed as early as 1856 , when the Court stated that Congress cannot "withdraw from [article III] judicial cognizance any matter which, from its nature, is the subject of a suit at the common law, or in equity, or admiralty." Murray's Lessee v. Hoboken Land \& Improvement Co., 59 U.S. (18 How.) 272, 284 (1856).

${ }^{109}$ Northern Pipeline, 458 U.S. at 70. But see id. at 104 (White, J., dissenting) (arguing that the "exceptional powers" test cannot be a legitimate limitation on Congress).

${ }^{110}$ Id. at 80 \& n.32 (plurality opinion); id. at 94 (White, J., dissenting).

${ }^{111}$ The various opinions in Northern Pipeline all seem to indicate that consent of the parties might affect the legislative courts analysis, although the question was not directly before the Court. See Northern Pipeline, 458 U.S. at 79 n.31; id. at 91 (Rehnquist, J., concurring); id. at 92 (Burger, J., dissenting); id. at 95 (White, J., dissenting). For criticism of the argument that consent legitimates delegations of judicial authority that would otherwise be violations of article III, see infra notes 149-53 and accompanying text.

112 See, e.g., American Fire \& Casualty Co. v. Finn, 341 U.S. 6, 16-17 (1951) (removal to 
litigant consent should not legitimate a legislative court in exercising jurisdiction which Congress lacks the constitutional power to grant in the first instance.

Thus, even assuming that certain aspects of the legislative court analysis might apply to adjudication by magistrates, Congress exceeded its power by authorizing magistrates to hear any civil matter within the jurisdiction of the federal district court. If only as a matter of the source and scope of their jurisdiction, magistrates exercise the "judicial Power of the United States."

\section{B. Magistrate Functions: Are Magistrates Adjuncts or Judges?}

Congress might also have empowered magistrates to make final decisions in federal court under its power to delegate particular court functions to judicial adjuncts. Indeed, both the House and Senate reports on the Magistrate Act saw the expansion of the magistrate's role under the 1979 Act as enlarging the powers of an "adjunct" officer of the district court. ${ }^{113}$ Adjunct status is also consistent with the historical development of magistrate powers: Congress initially granted magistrates only a limited ability to conduct hearings or hear motions, reserving to federal judges the power to make final decisions.

But the power of magistrates under the 1979 Act goes beyond that traditionally exercised by adjuncts. To determine whether the magistrates' power to make final, binding decisions with the consent of the litigants is consistent with article III, it is necessary to identify the limits on Congress's ability to empower adjuncts to perform particular adjudicatory functions normally performed by judges. Those limits mark the point at which magistrates cease to be mere adjuncts and begin to exercise the "judicial Power of the United States."

Under Crowell, a delegation of judicial functions to adjuncts violates article III if the the delegation removes "essential attributes" of judicial power from article III courts. ${ }^{114}$ In Raddatz the delegation survived that test; in Northern Pipeline it did not. When compared to the powers exercised by non-article III officers

federal court denied for lack of diversity of citizenship, which cannot be cured by consent of the parties).

${ }^{113}$ See Senate Report, supra note 13, at 3, reprinted in 1979 U.S. Code Cong. \& AD. NEws 1469, 1471 (magistrate is defined as a "judicial officer whose purpose was to assist the district judge"); HouSE REPORT, supra note 13, at 8 ("the magistrate is an adjunct of the United States District Court").

114 Crowell, 285 U.S. at 51; see supra notes 60-64 and accompanying text. 
in those cases, magistrate adjudication under the 1979 Act seems to fall outside the permissible scope of adjunct delegation.

Although the powers of magistrates differ in many respects from those at issue in Northern Pipeline, ${ }^{115}$ the magistrates nonetheless share many of the attributes that made the role of bankruptcy judges unconstitutional. Magistrates exercise the powers of district court judges during the trial or hearing, subject only to threat of removal to the district court in "extraordinary circumstances." court, ${ }^{112}$ and may bind future litigants as precedent. ${ }^{118}$ The decision typically is not reviewable by an article III judge except on appeal, and then is subject to the same standard of review as other district court decisions. ${ }^{119}$ In some respects magistrate power goes

115 For a description of the bankruptcy courts' powers under the Bankruptcy Act of 1978, Pub. L. No. 95-598, 92 Stat. 2459, see Northern Pipeline, 458 U.S. at 53-56. Magistrates are more like the old bankruptcy referees than like post-1978 bankruptcy judges. See id. at 79 n.31 (comparing the pre-1978 Bankruptcy referees with the post-1978 bankruptcy judges).

11628 U.S.C. $\$ 636$ (c) (1982). Unlike district court judges, however, magistrates do not have the power to punish for contempt. 28 U.S.C. \$ 636(e) (1982). In Geras v. Lafayette Display Fixtures, Inc., 742 F.2d 1037, 1044 (7th Cir. 1984), the court argued that the lack of the contempt power adequately distinguished magistrates' powers from those of federal judges: magistrates' power to enforce their decisions is more limited than that of judges. However, the civil contempt power is rarely used. See id. at 1049 (Posner, J., dissenting). Furthermore, magistrates do have the power to issue orders to show cause before the district judge why the person should not be held in contempt-and the judge is to hear evidence pertaining to the order in a "summary manner." 28 U.S.C. § 636(e) (1982). Finally, in Glidden Co. v. Zdanok, 370 U.S. 530, 570 (1962), the Court expressed its doubt "whether the capacity to enforce a judgment is always indispensable for the exercise of judicial power." There the fact that certain judgments of the Court of Claims were sometimes unenforceable because of subsequent congressional action did not bar a finding that the court exercised article III judicial power. Id. at 571 .

11 Geras, 742 F.2d at 1044 . The idea that entry of judgment is merely formal was refuted by the plurality in Northern Pipeline, 458 U.S. at 86 n.38 (" "The award of execution ... is a part, and an essential part of every judgment passed by a court exercising judicial power. It is no judgment in the legal sense of the term, without it.' ") (quoting Chief Justice Taney's memorandum in Gordon v. United States, 117 U.S. 697, 702 (1864)); see also Glidden Co. v. Zdanok, 370 U.S. 530, 568-69 (1962) (same).

118 It is not yet clear how much precedential value will be accorded to the final decisions of magistrates. To some extent this will depend upon how widely magistrates' decisions are disseminated. Nothing in the Magistrate Act prevents the publication of magistrates' decisions or their use as binding precedent. They are public documents, see Geras, 742 F.2d at 1051 (Posner, J., dissenting), and reporting services have made them available, see, e.g., USA Today v. Breakthrough Mktg., Inc., No. 84-5140 (E.D. Pa. Oct. 17, 1985) (available Nov. 25, 1985, on LEXIS, Genfed library, Dist file); Arnold v. Northwest Airlines, Inc., 18 Av. Cas. (CCH) I 18,255, 117 L.R.R.M. (BNA) 3381 (D. Minn. 1984); Ronholt v. United States, 84-2 U.S. Tax Cas. (CCH) I 9678 (W.D. Wash. 1984).

11028 U.S.C. $\$ 636$ (c)(3)-(4) (1982); cf. FED. R. Crv. P. 52(e)(4) (review of recommendations of masters); 42 U.S.C. $\S 405(\mathrm{~g})$ (1982) (review of administrative agency decisions). 
well beyond that formerly granted to the bankruptcy courts, since magistrates may determine any matter of fact or law within the district court's jurisdiction.

The magistrates' powers under the 1979 Act also exceed those approved in Raddatz. Raddatz approved delegation of adjudicatory functions to magistrates only where an article III judge retained final decisionmaking power. Magistrates now have the power to render final decisions without de novo review by an article III district judge. Although the magistrate scheme considered in Raddatz may effectively have permitted magistrates to make some final decisions, such decisions are of a completely different character in the absence of de novo review. Mandatory de novo review placed on article III judges a duty to examine the magistrates' findings and weigh the parties' objections before entering final judgment. By eliminating this duty, the present scheme grants to magistrates authority far beyond that permitted in Raddatz.

Some circuit courts have discounted the importance of de novo review because in practice judges may give the magistrate's findings cursory review or miss crucial credibility factors when determining the weight of the evidence. ${ }^{120}$ But even if de novo review does not "insure full Article III participation in the decision of every case," $"$ in1 does guarantee an active role for article III judges in adjudication. This participation assures greater control than that afforded by the threat of sua sponte removal. ${ }^{122}$

In another context, the Supreme Court has defined judicial power as "the power of a court to decide and pronounce a judgment and carry it into effect between persons and parties who bring a case before it for decision."123 The 1979 Magistrate Act vests precisely that power in magistrates. It removes the article III judge from the entire decisionmaking process-from the hearing of preliminary motions, to the taking of evidence and testimony, to the rendering of the final decision. ${ }^{124}$ The only decision made by the article III judge is whether to refer a particular case to a magis-

${ }^{120}$ See Pacemaker Diagnostic Clinic of Am., Inc. v. Instromedix, Inc., 725 F.2d 537, 546 (9th Cir.), cert. denied, 105 S. Ct. 100 (1984); see also Raddatz, 447 U.S. at 683 \& n.11 (comparing magistrates to masters, whose "recommendations are advisory only, yet this Court regularly acts on the basis of the master's report and exceptions thereto").

${ }^{121}$ Raddalz, 447 U.S. at 683.

12228 U.S.C. $\S 636(c)(6)(1982)$.

${ }^{123}$ Muskrat v. United States, 219 U.S. 346, 356 (1911) (discussing "case or controversy" requirement) (citation omitted).

${ }^{124}$ See House REPORT, supra note 13, at 9. 
trate. ${ }^{125}$ After delegation, the judge's role is entirely passive, except for the rare cases that present sufficient grounds to remove the case from the magistrate. ${ }^{126}$ Magistrates under the 1979 Act have become de facto judges exercising the "essential attributes" of the judicial power. ${ }^{127}$

Even proponents of the 1979 Act agree that to vest so much power in the magistrate without the consent of the parties would violate article III's express requirement that the "judges" of inferior courts be endowed with tenure and salary protections. But they assert that the consent of the parties to adjudication by a magistrate legitimates what would otherwise be an unconstitutional exercise of the federal judicial power. ${ }^{128}$ Crowell, Raddatz, and Northern Pipeline provide no analysis of the effect of consent. Instead, courts find precedent for this argument in two nineteenthcentury Supreme Court cases-Heckers v. Fowler ${ }^{129}$ and Kimberly $v$. $A r m s^{130}$-which approved the longstanding practice of adjudication by masters and referees with the consent of the parties. ${ }^{131}$

In Heckers the parties to a diversity action in federal court consented to be bound by the judgment of a state referee as if it were a judgment of the court. The lower court enforced the agreement, and ordered judgment to be entered in conformity with the referee's findings. ${ }^{132}$ On appeal, the Supreme Court affirmed, relying upon the historical practice of referring pending actions to referees whose findings were considered final if and only if the parties gave their consent beforehand and neither party later

125 The judge's role may be even more limited if he or she has issued a standing authorization for consensual reference to a magistrate, which was the procedure preferred in the House Report. See id.

128 That some cases might be removed from the magistrate under 28 U.S.C. $\S 636(c)(6)$ does not change the conclusion that, for those cases which are adjudicated by a magistrate, the statute has effectively removed the "essential attributes" of judicial power from the article III court.

${ }^{127}$ See Geras, 742 F.2d at 1046 (Posner, J., dissenting) (even though magistrates are not called "judges," "[w] hat they are called is not important; what they do is important").

128 See id. at 1042 (reference to magistrates cannot be sustained unless alternative of article III judge is "realistic and viable"); Pacemaker, $725 \mathrm{~F} .2 \mathrm{~d}$ at 542 ("Consent is important to the constitutional analysis.").

12969 U.S. (2 Wall.) 123 (1864). Heckers was a suit for breach of contract, with jurisdiction based on diversity.

130129 U.S. 512 (1889). Kimberly was also a contract suit with jurisdiction based on diversity.

131 See, e.g., Collins v. Foreman, 729 F.2d 108, 119 (2d Cir.), cert. denied, 105 S. Ct. 218 (1984); Pacemaker, 725 F.2d at 545; Wharton-Thomas v. United States, 727 F.2d 922, 928 (3d Cir. 1983).

13269 U.S. (2 Wall.) at 127. 
objected. ${ }^{133}$

In Kimberly the parties agreed that a master should decide the issues between them, and that the master's report should be subject to "like exceptions as other reports of masters." "134 The Supreme Court held that although the master's findings are "merely advisory" in the absence of the parties' consent, ${ }^{135}$ "the master [becomes] clothed with very different powers" when the parties consent to the reference. ${ }^{136}$ Where reference is consensual, the master's findings should "be taken as presumptively correct," and overturned only when "there has been manifest error" of fact or law. ${ }^{137}$

Essentially, Heckers and Kimberly were merely cases about enforcing the full scope of particular private agreements. The proper modern analogy to these cases is arbitration. The arbitrator's decision may be binding and ordinarily beyond the district court's review, but it is not an exercise of federal judicial power. ${ }^{138}$ Rather, parties to an arbitration agreement have consented to go outside the article III courts for adjudication by a private decisionmaker hired only to resolve the instant dispute. In contrast, adjudication by a magistrate, even on consent of the parties, is an exercise of judicial power entirely within the article III court by an officer of the court. ${ }^{139}$ The magistrate's final decision not only binds the parties at hand, but may also serve as precedent for subsequent litigation with the full weight and authority of any district court decision. ${ }^{\mathbf{1 4 0}}$

Even if Heckers and Kimberly are thought to involve delega-

193 Id. at 133.

134129 U.S. at 516-17 (quoting parties' agreement).

$135 \mathrm{Id}$. at 523.

${ }^{138}$ Id. at 524.

${ }^{137}$ Id.

${ }^{1 s 8}$ For a detailed discussion of the source of the arbitrator's power and the effect of his judgment, see Baker Indus. v. Cerberus, Ltd., 570 F. Supp. 1237, 1248-53 (D.N.J. 1983); see also United States v. Moorman, 338 U.S. 457 (1950).

${ }^{139}$ As the House Report noted, "[w] $[$ hen the magistrate tries a case, jurisdiction remains in the district court and is simply exercised through the medium of the magistrate." House REPORT, supra note 13 , at 8 . This view is also consistent with the argument made by several courts that consent to magistrate adjudication is a "choice of officers" within the federal court. See Geras v. Lafayette Display Fixtures, Inc., 742 F.2d 1037, 1041 (7th Cir. 1984) (consent is "parties" choice of . . . forum"); Wharton-Thomas v. United States, 721 F.2d 922, 926 (3d Cir. 1983) ("parties' consent went . . . to the judicial officer within the court who conducted the trial"); see also Muhich v. Allen, 603 F.2d 1247, 1251 (7th Cir. 1979) ("[j]urisdiction remains vested in the district court and is merely exercised through the medium of the magistrate").

${ }^{140}$ See supra note 118. 
tion of judicial functions to referees as officers of the court, their deference to litigant consent does not support the grant of final decisionmaking power to magistrates. In both cases the Court indicated that, regardless of consent, the federal judge retained the power to review the referee's findings before the entry of judgment. ${ }^{141}$ Federal courts retain no such power with regard to final decisions of magistrates. While "extraordinary circumstances" may result in removal of the case from the magistrate, the 1979 Act precludes review of the magistrate's decision before it is entered as the district court's final decision. ${ }^{142}$ To use the language of Raddatz, the "ultimate decision" rests with the magistrate, not the article III judge. ${ }^{143}$

Moreover, Heckers and Kimberly contain no analysis relevant to the constitutional objections to the Magistrate Act. The Court ruled only on the validity of individual masters' decisions under the "peculiar circumstances" of each case; ${ }^{144}$ it did not consider the validity of a statutory scheme to institutionalize adjudication by non-article III officers. In sum, Heckers and Kimberly provide no persuasive authority for the proposition that litigant consent removes the serious article III concerns that inhere in Congress's delegation of adjudicatory authority to magistrates.

\section{Is the Magistrates' Exercise of Judicial Power Consis- tent with Article III Principles?}

The previous section has shown that the 1979 Act's grant of final decisionmaking power to magistrates exceeds the accepted limitations upon the power that Congress may grant to legislative courts or judicial adjuncts. The Act thus constitutes a grant of "judicial Power" to non-article III officials. Under the "constitutional principles" approach, this requires the conclusion that the Act is unconstitutional. However, as Thomas shows, the inquiry under a

${ }^{141}$ The Court expressly noted that the referee's report was filed without objection, and apparently considered this as relevant a factor as were reference and consent: "Judgment having been entered without objection, and pursuant to the order of the court and the agreement of the parties, it is not possible to hold that there is any error in the record." Heckers, 69 U.S. (2 Wall.) at 133.

14228 U.S.C. $\$ 636$ (c) (1982).

${ }^{143} 447$ U.S. at 683. This same consideration also distinguishes the power of the magistrate from that of the modern master under rule 53 of the Federal Rules of Civil Procedure. Unlike the magistrate under the 1979 Act, the master does not have the power to enter final judgment. The master's report is reviewable by the district court which may accept or reject the report. Although the master's report is entitled to deference or review on a "clearly erroneous" standard, the court need give no deference to the master's findings of law.

${ }^{144}$ Heckers, 69 U.S. (2 Wall.) at 133. 
"due process" approach now shifts to whether the extent of the Act's intrusion upon "judicial Power" is warranted by the purposes of the delegation. In other words, do the purposes served by the Magistrate Act outweigh its negative effect on article III values?

On one side of the balance are the immediate benefits of magistrate adjudication. Increasingly crowded federal courts and resulting delays make it impossible to deny the need for measures to enhance the efficiency of federal courts. Magistrates help the federal courts adjudicate a greater number of cases without the need for additional judges. In fact, the "success" of magistrate adjudication is evidenced by the fact that the number of cases heard by magistrates has increased annually. ${ }^{145}$

On the other side are the costs to article III values inherent in these benefits. The courts which have used the "due process" approach to approve the Magistrate Act have recognized two article III values: litigant rights and the separation of powers. However, the courts have greatly underestimated the extent to which magistrate adjudication compromises those values, and have ignored other important article III values that are seriously undermined by the 1979 Act.

\section{A. Magistrate Adjudication and Litigant Rights}

Some proponents of the 1979 Act argue that the central purpose of article III is to protect the rights of litigants. The "right" to an article III judge is like other fundamental rights that the individual can waive, such as the right to a jury trial, the right to be free from self-incrimination, and even the right to trial itself. ${ }^{146}$ If this is true, the consent requirement renders magistrate adjudica-

145 In 1983, magistrates heard 1,933 cases pursuant to their powers under 28 U.S.C. $\S 636$ (c). In 1984, this number rose to 3,546. From 1983 to 1984 , the magistrates' caseload increased at an annual rate of 13.4 percent. Administrative OfFice of the UnITED STates Courts, The United States Courts: A pictorial summary 4 (1984). In addition, the number of magistrates has increased significantly. The number of authorized positions for magistrates rose from 61 in early 1970, to 228 in fall, 1982. Carroll Seron, The Roles of Magistrates in Federal District Courts 11 (1983). For a general description of the magistrate system after the passage of the 1979 Act, including recommendations for further reform, see The Federal Magistrates System: Report to Congress by the Judicial Conference of THE UNITEd States (1981). A more recent study of magistrate adjudication is presented in Carrol Seron, The Roles of Magistrates: Nine Case Studies 59-68 (1985) (describing magistrate adjudication in practice in nine district courts) [hereinafter cited as C. SERoN, Nine Case Studies].

${ }_{1 \times 6}$ See, e.g., Pacemaker Diagnostic Clinic of Am., Inc. v. Instromedix, Inc., 725 F.2d 537, 543 (9th Cir.), cert. denied, 105 S. Ct. 100 (1984). 
tion consistent with article III. ${ }^{147}$ Litigants can protect their rights by insisting on adjudication by an article III judge, but may choose to waive those rights by consenting to magistrate adjudication. ${ }^{148}$

This line of argument is based on an incomplete interpretation of article III. First, article III is about much more than litigant rights; it defines important limits on congressional authority and delineates the role of the judiciary in the constitutional framework of government. ${ }^{149}$ Litigants decide whether to consent to magistrate adjudication on the basis of pragmatic considerations such as likelihood of success and speed of resolution. They have little personal interest in protecting values such as the separation of federal powers, the allocation of powers between the states and the federal government, or the public's interest in maintaining a highly qualified, impartial judiciary. ${ }^{150}$ Nor are these concerns vindicated by review or removal for actual violations of due process. Reduced judicial impartiality will seldom result in measurable injury to the litigant.. ${ }^{161}$

Second, even if litigant rights are considered the sole concern of article III, the 1979 Act inadequately protects those rights. The consent requirement only protects the rights of litigants involved in the particular case. But parties not involved in the case will also be affected by the magistrate's decision. Because the magistrate's decision is entered as the final decision of the district court, it potentially has full precedential value and may influence the results of subsequent cases. ${ }^{152}$ Thus, litigants in later suits have an interest in assuring that a case which may bind them as precedent is adjudicated by a judge whose impartiality is protected by article III. The consent requirement in the 1979 Act does nothing to pro-

${ }^{147}$ See, e.g., Geras v. Lafayette Display Fixtures, Inc., 742 F.2d 1037, 1041-42 (7th Cir. 1984); Pacemaker, 725 F.2d at 541-43.

${ }_{148}$ See Lehman Bros. Kuhn Loeb, Inc. v. Clark Oil \& Refining Corp., 739 F.2d 1313, 1315 (8th Cir. 1984); Goldstein v. Kelleher, 728 F.2d 32, 36 (1st Cir.), cert. denied, 105 S. Ct. 172 (1984); Pacemaker, 725 F.2d at 543.

149 See supra text accompanying notes 23-33.

150 At least one commentator has argued that article III endows no "right to an article III judge" since the tenure and salary provisions were intended primarily as a structural provision to ensure against encroachments on judicial power by the legislative or executive branches, not merely as protection for individuals' rights. Note, Federal Magistrates and the Principles of Article III, supra note 16, at 1952-54. Litigants should not be able to "waive" the structural provisions of the Constitution.

151 The Supreme Court has shown that it is aware of this problem. For example, in Glidden Co. v. Zdanok, 370 U.S. 530 (1962), the Court overturned a decision in which a nonarticle III judge had participated in deciding a case in federal court, even though there was no showing of de facto injury or violation of due process.

${ }^{162}$ See supra note 118. 
tect this interest. ${ }^{153}$

\section{B. Magistrate Adjudication and Structural Values}

1. Judicial Independence. Magistrates remain subject to tenure and salary manipulation by Congress: magistrates are appointed for limited terms and Congress can reduce their salaries at any time by amending the statute. Nonetheless, the circuit courts have argued that judicial control over magistrates satisfies article III by protecting adjudication from legislative and executive interference. The main purpose of article III, they argue, is to protect the judicial branch from influence by the political branches; Congress can vest judicial authority in non-article III officers if it provides sufficient procedural protections against such influence.

The courts point to four mechanisms that are supposed to guarantee that the judiciary controls the magistrates. ${ }^{154}$ First, district court judges control magistrates through the case reference process, which requires the judge to "specially designate" a magistrate before the magistrate can exercise authority under the Act. ${ }^{165}$

${ }^{153}$ A less compelling objection to the consent argument focuses on the voluntariness of consent. Magistrate adjudication arguably involves hidden "coercion" rendering the parties' consent involuntary. The Senate Report explicitly stated that the Act was intended to make the federal courts more accessible to the "less-advantaged" who "lack the resources to cope with the vicissitudes of adjudication delay and expense." SEnate REPORT, supra note 13, at 4, reprinted in 1979 U.S. Code CoNG. \& AD. News at 1472. As long as litigation before a district court judge requires more time and expense than does magistrate adjudication, individuals will feel pressured to consent to trial by magistrate. See Pacemaker, 725 F.2d at 554 (Schroeder, J., dissenting). This is especially true in criminal cases, where the alternative to consent by magistrate may be a longer stay in jail for those who lack sufficient resources to make bail. Additionally, a litigant may feel pressure to consent to magistrate adjudication so as not to irritate the judge who would then have to hear the case. See C. SERON, NinE CASE STuDies, supra note 145, at 61, 65 (describing how lawyers feel they "have little choice" but to consent when the judge raises the issue).

Nevertheless, this objection based on voluntariness is not decisive for several reasons. First, the Act empowers the district court to adopt "procedures to protect the voluntariness of the parties' consent." 28 U.S.C. $\$ 636$ (c)(2) (1982); see also FED. R. Civ. P. 73(b) ("No . . court official shall attempt to persuade or induce a party to consent to a reference of a civil matter to a magistrate ... ."). The "voluntariness" of litigant consent also may be reviewed on appeal as a matter of due process, or may constitute grounds for removing the case to the district court. But see Swallow Turn Music v. Tidal Basin, Inc., 581 F. Supp. 504 (D. Me. 1984) (consent cannot be withdrawn in the absence of coercion or "extraordinary circumstances"). Even though voluntariness could be a concern in individual cases, it is not a problem unique to magistrate adjudication or one that the courts are unaccustomed to dealing with in the context of waiver of other rights. It therefore seems unlikely that an objection based on voluntariness can create a constitutional bar to magistrate adjudication except, perhaps, in individual cases on due process grounds.

154 See, e.g., Pacemaker, 725 F.2d at 544-45.

$1 s 528$ U.S.C. $\$ 636(c)(1)$ (1982). The House Report states that it is preferable that the district court authorize the magistrate to hear and decide cases under a standing general 
The district court judge also has the power to rescind an earlier referral to the magistrate upon the court's own motion "for good cause shown," or upon "extraordinary circumstances" shown by the parties. ${ }^{156}$ Article III judges maintain further control over magistrate decisions through appellate review in either the district or circuit courts. ${ }^{157}$ Finally, the appointment and removal of magistrates is entirely in the hands of article III judges. Judges determine the number of magistrates in each district ${ }^{158}$ and select and remove magistrates within certain statutory standards of fitness and performance. ${ }^{159}$

Despite these control mechanisms, tenured judges do not participate in magistrate adjudication to the extent required by article III. First of all, the referral, removal, and appeal provisions allow a significant number of cases to be adjudicated entirely by magistrates. The requirement of formal referral will not deter judges from delegating cases to magistrates; as the docket increases judges will have an incentive to refer as many cases as possible to magistrates. ${ }^{160}$ And once referred, few cases are likely to present the "extreme circumstances" required for removal. ${ }^{161}$ Even fewer cases

authorization, HouSE REPORT, supra note 13, at 11, although the statute does not on its face bar case-by-case reference of matters to the magistrate. See C. SERon, Nine Case Studres, supra note 145, at 66-67 (in some districts previously designated magistrates are assigned randomly after party consent).

1se 28 U.S.C. $\S 636(c)(6)$ (1982).

${ }^{157} I d$. \$ 636(c)(3)-(4) (magistrate's decision appealable to court of appeals unless parties consent at time of reference to appeal to district court). In Northern Pipeline, Justice White argued that the availability of appeal to an article III court tipped the balance in favor of constitutionality of the bankruptcy courts. See Northern Pipeline, 458 U.S. at 11516 (White, J., dissenting).

${ }^{158} 28$ U.S.C. $\S 633$ (b) (1982).

150 Id. $\S 631$ (i) (providing for removal of magistrates for "incompetency, misconduct, neglect of duty, or physical or mental disability").

${ }^{100}$ As district court caseloads rise, it is more likely that the requirement of consent will act as the only effective check on the "wholesale delegation" of cases to magistrates. Collins v. Foreman, 729 F.2d 108, 119-20 (2d Cir.), cert. denied, 105 S. Ct. 218 (1984). As one dissenter noted, if the judges had the time to consider the reference of each case individually, and then to consider whether that reference should be vacated sua sponte, there would be no need to create magistrate positions. See Pacemaker, 725 F.2d at 552 (Schroeder, J., dissenting).

${ }^{161}$ Precisely what is meant by "good cause" or "extraordinary circumstances" has yet to be determined, although the few district courts which have considered the question suggest that it must be more than mere dissatisfaction with the magistrate's handling of the trial. E.g., Swallow Turn Music v. Tidal Basin, Inc., 581 F. Supp. 504, 510 \& n.8 (D. Me. 1984); Southern Agriculture Co. v. Dittmer, 568 F. Supp. 645, 646 (W.D. Ark. 1983); Gomez v. Harris, 504 F. Supp. 1342, 1345 n.6 (D. Alaska 1981). The Senate Report on the Magistrate Act states that the removal power is "to be exercised only where it is appropriate to have the trial before an article III judicial officer because of the extraordinary questions of law at issue and judicial decisionmaking is likely to have wide precedential importance." 
will be subject to scrutiny by an article III judge on appeal; factual determinations might never be subject to meaningful review. In any event, Northern Pipeline stands squarely for the proposition that a chance to appeal a non-article III officer's decision to an article III court does not validate an otherwise unconstitutional delegation. ${ }^{162}$ In sum, as one court conceded in defending the Act, "a radical shift to trial by magistrate could easily result in a finding of unconstitutionality" as the "reality" of judicial control over magistrate authority declines. ${ }^{163}$

Even beyond its questionable effectiveness in protecting magistrates from control by the political branches, judicial control of magistrates is deeply flawed as a mechanism for safeguarding constitutional values. Indeed, whatever indirect control the 1979 Act allows article III judges to exert over magistrates is itself inconsistent with the nature of judicial decisionmaking required by article III. District court judges have the power to appoint and to remove magistrates. ${ }^{164}$ This power is inconsistent with the understanding represented by article III that "[n]o matter how strong an individual judge's spine, the threat of punishment-the greatest peril to judicial independence-would project as dark a shadow whether cast by political strangers or by judicial colleagues."165 The tenure and salary provisions of article III protect judges not only from the political branches, but from undue influence by other judges as

Senate Report, supra note 13, at 14, reprinted in U.S. Code Cong. \& AD. NEwS at 1483. It is clear that the effectiveness and utility of magistrate adjudication would be quickly undermined if courts readily granted relief when the litigants raised post-consent objections. For a discussion of how the standard for removal might be applied, see Note, Federal Magistrates and the Principles of Article III, supra note 16, at 1960-61.

${ }^{162}$ Northern Pipeline, 458 U.S. at 86 n.39; id. at 91 (Rehnquist, J., concurring). The Constitution clearly states that article III's tenure and salary protections apply to judges "both of the supreme and inferior Courts." U.S. Const. art. III, $\S 1$ (emphasis added).

${ }^{163}$ Geras v. Lafayette Display Fixtures, Inc., 742 F.2d 1037, 1045 (7th Cir. 1984).

16428 U.S.C. § 631(b)-(d) (1982) (appointment); id. § 631(i) (removal).

${ }^{165}$ Kaufman, supra note 29, at 714; see also Note, Article I Courts, supra note 13, at 583-85. In Raddatz, Justice Blackmun stated in dictum that delegation of certain judicial functions to magistrates is constitutional because "the only conceivable danger of a 'threat' to the 'independence' of the magistrate comes from within, rather than without, the judicial department." 447 U.S. at 685 (Blackmun, J., concurring). This statement would appear to express the view that article III was not intended as a protection against threats from within the judiciary. But the statute in question in Raddatz, unlike the 1979 Act, did not grant final decisionmaking power to magistrates. While Justice Brennan's plurality opinion in Northern Pipeline cited this dictum with apparent approval, 458 U.S. at $79 \mathrm{nn} .30$ \& 31 , the citations appeared in the course of his discussion of Raddatz. Elsewhere in his opinion, Justice Brennan noted as a matter of general principle that " $t$ ] $]$ he guarantee of life tenure insulates the individual judge from improper influences not only by other branches but by colleagues as well, and this promotes judicial individualism." 458 U.S. at 59 n.10. 
well. ${ }^{166}$ Magistrates cannot be truly independent with regard to the cases before them as long as they are subject to indirect control by district court judges.

The ultimate effect of magistrate adjudication, then, is to remove a significant number of cases from any participation by article III officials. Some cases adjudicated by magistrates will involve direct participation by article III judges through appellate review,

${ }^{168}$ Since the Court has dealt mostly with cases involving legislative encroachment on judicial power, much of its discussion of the tenure and salary provisions of article III has focused on the separation of powers. In only one case, Chandler v. Judicial Council, 398 U.S. 74 (1970), has the Court expressly considered the question of judicial interference in the independence of the federal judge. There the Court considered whether the judicial council of the Tenth Circuit could deprive a district court judge of the power to take action on cases filed in the district court on which he served. The Court suggested that the issue raised article III concerns, id. at 84 , but did not finally resolve the issue, id. at 87-89.

The outcome of Chandler indicates that federal judges may be subjected to a considerable amount of control by other judges, at least in regard to administrative matters. In dissent, however, Justice Douglas implied and Justice Black clearly stated that article III was also meant to preserve the independence of the judge from tampering even by other article III judges. See id. at 136-37 (Douglas, J., dissenting); id. at 141-42 (Black, J., dissenting).

This position finds support in article II of the Constitution. Article II gives the Senate and not the judiciary the power to impeach a judge for "high Crimes and Misdemeanors." U.S. CoNST. art. II, § 4. The question of whether the Constitution requires that judges, at least of the "inferior courts," be removable only by impeachment has been the subject of considerable debate. Compare Raoul Berger, Impeachment: The Constitutional Problems 122-80 (1973) with Kurland, The Constitution and the Tenure of Federal Judges: Some Notes from History, 36 U. CHI. L. REv. 665, 667 (1968) ("there is no point in tinkering with the independence of federal judges by subjecting their tenure to control of other federal judges appointed by the same defective process"). But the Supreme Court has consistently adhered to the view that federal judges can be removed only by impeachment. See Northern Pipeline, 458 U.S. at 59; Chandler, 398 U.S. at $141-42$ (Black, J., dissenting); United States ex rel. Toth v. Quarles, 350 U.S. 11, 16 (1955).

Congress may have also violated article II by empowering judges to appoint magistrates. Federal judges must be appointed by the President with the advice and consent of the Senate. See 2 Joseph Story, Commentaries on the Constitution of the United STATES $402 \mathrm{n} .2$ (1873). Several courts have argued that Congress may provide for the judicial appointment of magistrates without the advice and consent of the Senate because the Constitution allows Congress to vest "in the Courts of Law" the power to appoint "inferior Officers" of the United States. U.S. CoNsT. art. II, § 2; see Go-Bart Importing Co. v. United States, 282 U.S. 344, 352-53 (1931) (commissioners may be appointed by district courts as inferior officers); Rice v. Ames, 180 U.S. 371, 378 (1901) (Congress may authorize judges to appoint commissioners). But this argument begs the question by assuming that magistrates are "inferior Officers." Magistrates do seem to be "inferior Officers" with regard to some of their functions. But when they exercise "the judicial Power of the United States," they may cease to be inferior officers, becoming instead de facto federal judges. See Pacemaker, 725 F.2d at 549-50 (Schroeder, J., dissenting) (arguing that "inferior officers" refers to such officers as clerks of court, not officers who exercise article III power); $c f .28$ U.S.C. $\$ 171$ (1982) (stating that judges of the United States Claims Court, an article I court, are appointed by the President with approval by the Senate). Since the power to choose who will exercise federal judicial power is a significant component of the Constitution's system of checks and balances, it should not be lightly removed from the President and the Senate. 
but such participation is constitutionally inadequate. And to the extent that the Act attempts to provide indirect control as a substitute, it alters the judicial decisionmaking process in a way that destroys the judicial independence required by article III.

2. Federalism and the Public Interest. The circuit courts have also ignored the effect that adjudication by magistrates lacking article III protection has on the relationship between the states and the federal government. Because federal courts exert jurisdiction over diversity cases arising entirely under state law and cases in which states are parties, article III protects state interests in the operation of federal courts. ${ }^{167} \mathrm{By}$ allowing magistrates to decide these cases even though their decisions may be influenced both by factors within the judicial branch and by congressional tampering with salary levels or the appointment process, the Act violates the states' interests in having state law issues adjudicated in federal court by independent article III judges. Furthermore, some decisions by state judges are subject to federal review and reversal, and magistrate adjudication could well undermine the authority of federal judges by weakening state judges' respect for the federal judiciary. ${ }^{168}$

Lastly, the vesting of final decisionmaking authority in magistrates violates the public's interest in accurate and impartial adjudication by the federal judiciary. Magistrates are now authorized to decide issues of national scope and importance, to hold federal and state statutes unconstitutional, and to issue decisions which may have precedential impact on subsequent litigation. If article III's tenure and salary requirements play any part in improving the quality of federal adjudication-and the clear thrust of article III is that they do-there is good reason to doubt the wisdom of permitting magistrates to wield such broad powers.

In sum, the apparent practical advantages of the 1979 Act do not outweigh its harm to article III values. Indeed, the foregoing discussion suggests that many of the fundamental values protected by article III, while perhaps less tangible than a quick reduction in the judicial caseload, are potentially much more important and farreaching. ${ }^{169}$ The Constitution specifies the powers of each branch

${ }^{167}$ See supra notes 30-31 and accompanying text.

188 See, e.g., Wingo v. Wedding, 418 U.S. 461, 465 (1974) (magistrate conducted habeas corpus review of state court proceedings after remand by circuit court).

${ }^{168}$ Cf. INS v. Chadha, 462 U.S. 919, 959 (1983) ("There is no support in the Constitution or decisions of this Court for the proposition that the cumbersomeness and delays often encountered in complying with explicit constitutional standards may be avoided, either by the Congress or by the President."). 
of government as a safeguard against expedient modifications of a careful balance. As the ultimate arbiters of the Constitution, federal judges should be particularly careful in interpreting structural provisions relating to their own authority, and should remember the full range of purposes that guided the framers of article III-despite their implications for the burdens of judicial office.

\section{Conclusion}

Regardless of whether one adopts the "constitutional principles" approach or the "due process" approach to interpreting article III, the Federal Magistrate Act of 1979 transgresses the limits that article III has placed on Congress's power to delegate judicial authority to officials not granted life tenure and salary protection. The Act extends to magistrates the major portion of the jurisdiction of the federal courts and the key functions of the federal judge. Empowered to enter a final decision, magistrates become de facto federal judges. As a result, particular cases are entirely removed from active consideration by judges with the tenure and salary protections of article III. Consent, which protects the litigants in the instant case to some extent, fails to protect non-parties, and provides no safeguard against erosion of the structural values served by article III. And the Act's scheme of judicial control, although intended to protect against executive and legislative interference, may result in an even greater threat to the independence and impartiality of magistrates as final decisionmakers. Although the expansion of magistrate adjudication may bring immediate practical benefits to federal district court judges, it creates a direct conflict with many of the fundamental values underlying article III. 